\title{
The histological study of human fetal spleen
}

\author{
Ajit Holkunde ${ }^{1}$, Supriya Sakhare ${ }^{2, *}$ \\ Assistant Professor, ${ }^{1}$ Dept. of Anatomy, ${ }^{2}$ Dept. of Physiology, Smt. Kashibai Navale Medical College \& General Hospital, \\ Narhe, Pune, Maharashtra, India
}

*Corresponding Author:

Email: drsupriyasakhare@gmail.com

Received: $20^{\text {th }}$ January, 2018

Accepted: $26^{\text {th }}$ February, 2018

\begin{abstract}
In the present observational study, thirty aborted human fetuses of 13-38 weeks gestational age with no obvious congenital abnormality were obtained. To study the histology of spleen in relation to the gestational age, spleen was procured after dissection of fetuses and slides were prepared with $\mathrm{H} \& \mathrm{E}$ staining. The findings were noted under the light microscope. On looking over the literature on development and the important functions served by the spleen as haemopoeitic and lymphoid organ, the following study was undertaken. In the study, the mean body weight of fetuses was 130.83 at $14^{\text {th }}$ week and $3150 \mathrm{gm}$ at the age of $38^{\text {th }}$ week. The average crown rump length of fetuses at 14 weeks was $115 \mathrm{~mm}$ and was $330 \mathrm{~mm}$ at $38^{\text {th }}$ week. Histologically, at $13^{\text {th }}$ week of age there were large numbers of cells of irregular shape with large nucleus centrally. Few small thin walled vessels are seen. At $20^{\text {th }}$ week of age, clearcut division of red and white pulp was seen. Our study may be regarded as a preliminary study including some detailed results. The histological findings acquired in our study will be beneficial for the evaluations about the fetal spleen.
\end{abstract}

Keywords: Human fetus, Spleen, Histology.

\section{Introduction}

The study of development of human being is always a subject of interest of many researchers.

Each and every organ of human body executes many important functions, helpful for the survival of human being in this world. Embryologists are very keen in knowing the development of every organ of human being.

One of the important among these is the spleen. The spleen is known to human beings since classical times. Histologically, the spleen is surrounded by a capsule composed of dense fibrous tissue, elastic fibers, and smooth muscle. The outermost layer of the splenic capsule is composed of mesothelial cells, which may not be evident on histologic section. Irregularly spaced trabeculae of smooth muscle and fibroelastic tissue emanate from the capsule into the splenic parenchyma. These trabeculae also contain blood and lymph vessels and nerves. The lymph vessels are efferent vessels through which lymphocytes migrate to the splenic lymph nodes. (Cesta MF). ${ }^{1}$

As the spleen is playing important role in haematopoiesis and immunological functions, development of it is important to know.

To anyone looking over the literature on the development of spleen the necessity for more work on finer details of process is evident. The most extensive work has been done on the lower vertebrates and very few on human embryos. On looking over the literature on development and the important functions served by the spleen as haemopoeitic and lymphoid organ, the following study is undertaken.

\section{Aims and objectives}

To study the histological and developmental changes in human fetal spleen at various gestational age of fetus.

\section{Materials and Methods}

Thirty aborted human fetuses of 13-38 weeks gestational age with no obvious congenital abnormality were obtained with the permission of Professor and Head of department of Obstetrics and Gynecology of our medical college and prior consent of the parents. The study was approved by the Ethical Committee of our college. These fetuses included spontaneous abortions and stillborns. Fetuses were obtained within 4-5 hours of birth to avoid post-mortem changes.

\section{Materials used:}

1. Double pan balance, chemical balance measuring scale and vernier caliper.

2. Permanent marker.

3. Plastic tag, scissors, scalpel and forceps.

4. Rubber gloves and filter paper.

5. Rotary microtome, reagents, stains, slides with coverslip.

6. Light microscope and digital camera

Measurements of External parameters:

Following parameters were measured:

1. The sex, gestational age was noted from the case paper.

2. The crown rump length: It was recorded by using thread and scale and measured in $\mathrm{mm}$. 
Fixation of fetuses: The fetuses were fixed by injecting $10 \%$ formalin locally into the various body cavities with the help of $10 \mathrm{cc}$ syringe and 20 number needle for better preservation.

\section{Dissection, measurement and fixation of spleen:}

1. The fetuses were carefully dissected by doing the window dissection to remove the spleen in one piece.

2. The spleen was weighed in chemical balance and recorded in grams.

3. The spleen was cut into pieces and fixed in $10 \%$ formalin for 24-48 hours.

4. After fixation, the paraffin wax blocks were prepared with the embedded splenic tissue in it.

\section{Staining:}

1. The slides were prepared with the proper $H \& E$ staining method and were lebelled according to the gestational age.

2. The stained slides were observed under light microscope using $4 \mathrm{X}, 10 \mathrm{X}$ and $40 \mathrm{X}$ magnification and the findings were noted and compared with previous studies.

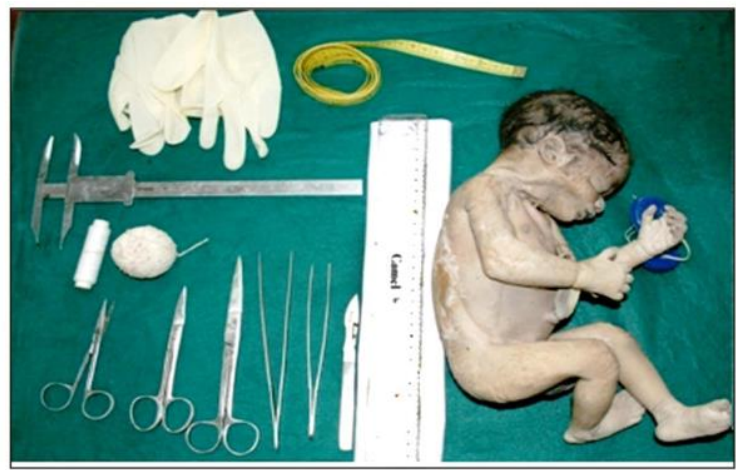

Fig. 1: Showing fetus of 24 weeks with materials used

\section{Observations and Results}

The present study was carried out over 30 human fetuses ranging from the $13^{\text {th }}$ week to $38^{\text {th }}$ week of gestational age. The gestational age of fetuses was determined with the help of case paper, obstetric history of mother and the ultrasonography. For the study purpose and for comparison with other workers, the fetuses were arranged in the 13 groups. When there was more than one fetus from a particular age group, average was calculated for each group.

To study the development and histological changes in the spleen in relation to gestational ages, following parameters were studied.

1. Body weight and crown rump length of fetus:
This data was tabulated (table-1)

Table 1: Showing average body weight (grams) and crown-rump length against weeks of gestation

\begin{tabular}{|c|c|c|c|}
\hline $\begin{array}{c}\text { Gestational } \\
\text { age group } \\
\text { (weeks) }\end{array}$ & $\begin{array}{c}\text { Number of } \\
\text { fetuses in } \\
\text { the group }\end{array}$ & $\begin{array}{c}\text { Body } \\
\text { weight } \\
\text { (gms) }\end{array}$ & $\begin{array}{c}\text { Crown- } \\
\text { rump } \\
\text { length(mm) }\end{array}$ \\
\hline 14 & 3 & 130.83 & 115 \\
\hline 16 & 2 & 200 & 122 \\
\hline 18 & 2 & 300.25 & 150 \\
\hline 20 & 2 & 420.50 & 172 \\
\hline 22 & 2 & 610 & 185 \\
\hline 24 & 3 & 802 & 202 \\
\hline 26 & 2 & 1150 & 224 \\
\hline 28 & 2 & 1290 & 270.5 \\
\hline 30 & 3 & 1725 & 276 \\
\hline 32 & 2 & 1924 & 295 \\
\hline 34 & 2 & 2480 & 300 \\
\hline 36 & 3 & 2910 & 324.5 \\
\hline 38 & 2 & 3150 & 330 \\
\hline
\end{tabular}

2. Histological study of spleen: Slides of the spleen of each gestational age were prepared and stained with haematoxylin-eosin and studied under light microscope.

At $14^{\text {th }}$ week of age:

1. Capsule was seen.

2. Reticular cells forming network were present.
3. More number of blood vessels were present.

4. Numbers of hemopoietic cells were increased.

5. Lymphoblasts were seen in groups, but these groups were scattered.

At $16^{\text {th }}$ week of age:

1. Capsule was thickened and prominent. 
2. Reticular cells forming fibers were seen and were forming the network.

3. Haemopietic cells are seen in large numbers.

4. Majority of WBC seen were lymphocytes, arranged in groups.

5. These groups are scattered randomly all around.

6. These connective tissue were seemed to be supporting the sinusoids.

7. Vascularity was increased as the number of blood vessels was increased.

At $18^{\text {th }}$ week of age:

1. The vascularity was increased further.

2. Capsule along with few trabeculae was prominently seen.

3. Lymphocytes were arranged in groups.

4. At the margin of these groups, sinusoids and large number of RBC's were noted.

5. The division of white and red pulp was noted firstly in this age.

6. But the lymphocytes were less compactly arranged and their association with arteriole was not prominently seen.

At $20^{\text {th }}$ week of age:

1. Capsule was seen prominently.

2. Trabeculae were seen easily.

3. Large number of blood vessels were noted.

4. Clearcut division of red and white pulp was seen.

5. White pulp consisted of compactly arranged lymphocytes surrounding the arteriole as the periarteriolar sheath.

6. In between the white pulp, red pulp can be seen consisting of sinusoids and RBCs.

From $22^{\text {nd }}$ to $38^{\text {th }}$ week of age:

1. Structure was similar to the adult spleen.

2. Thickened well defined capsule was seen.

3. Number of trabeculae were present.

4. Spleen showed rich vascularity showing large number of arterioles.

5. Division of red and white pulp was seen prominently.

6. In white pulp, lymphocytes were compactly arranged and arterioles were eccentric in position.

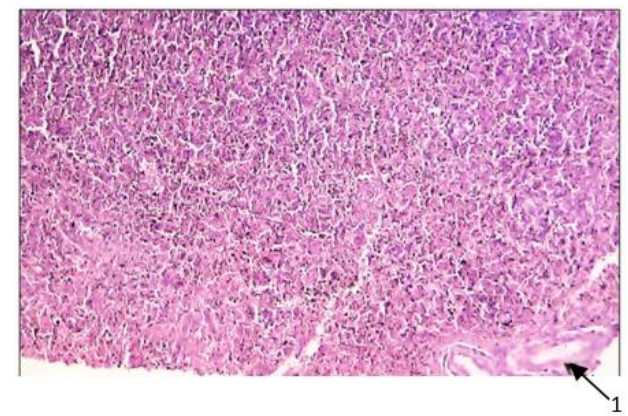

Fig. 2: Slide of spleen of age- $14^{\text {th }}$ week $(10 x)$ showing blood vessel (1)

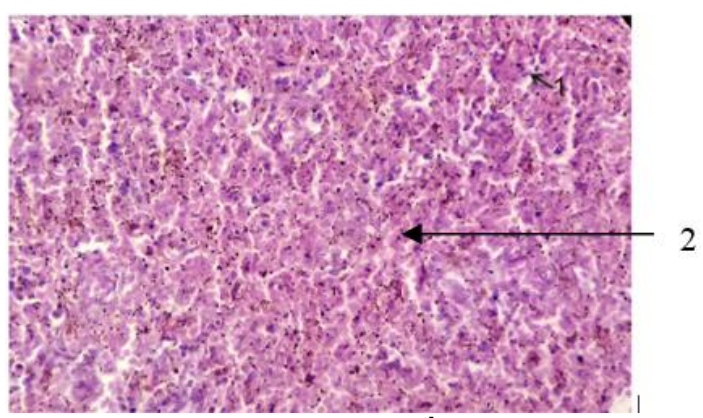

Fig. 3: Slide of spleen of age-14 ${ }^{\text {th }}$ week $(40 x)$ showing lymphoblasts(1) and Reticular cells(2)

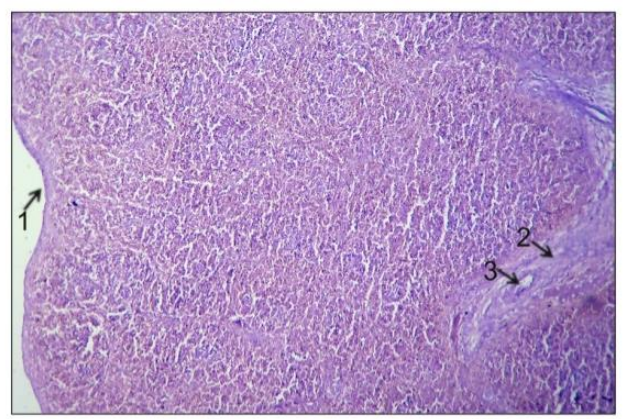

Fig. 4: Slide of spleen of age- $16^{\text {th }}$ week fetus $(10 x)$ showing capsule(1), trabeculae(2) and trabecular vessels (3)

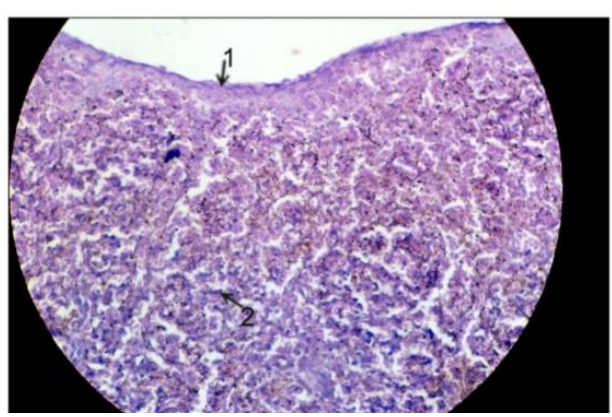

Fig. 5: Slide of spleen of age- $16^{\text {th }}$ week fetus $(40 x)$ showing capsule(1), lymphocytes(2)

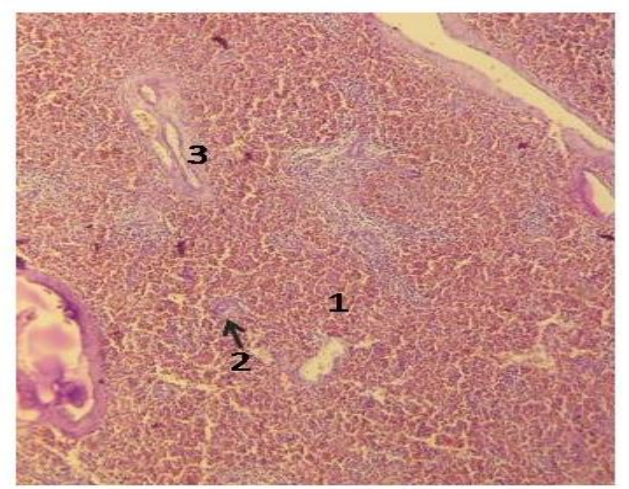

Fig. 6: Slide of spleen of age- $2^{\text {th }}$ week fetus (10x) showing red pulp(1), white pulp(2) and blood vessels (3) 


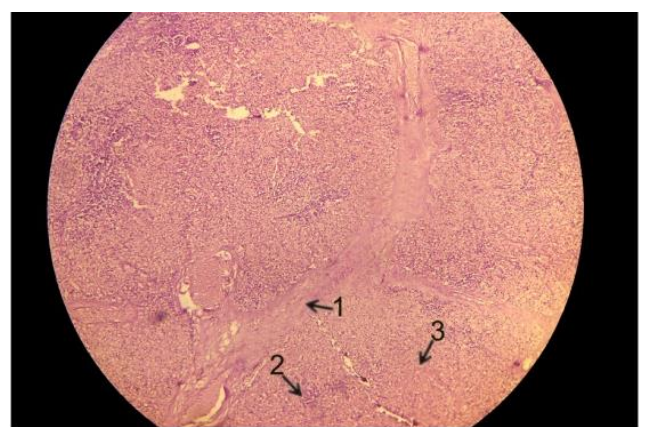

Fig. 7: Slide of spleen of age- $34^{\text {th }}$ week fetus (10x) showing trabeculae(1), white pulp(2) and red pulp(3)

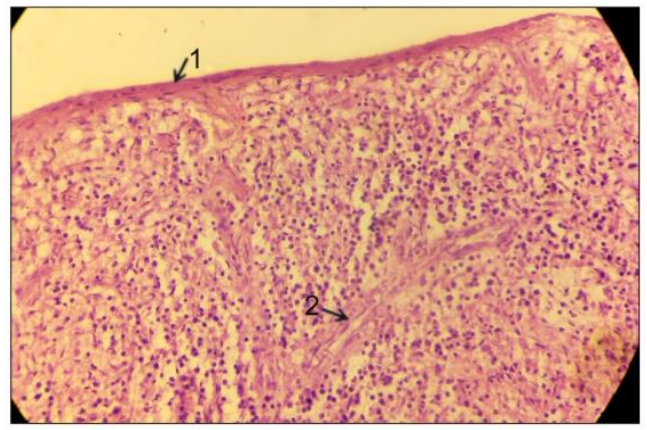

Fig. 8: Slide of spleen of age- $38^{\text {th }}$ week fetus $(40 x)$ showing capsule (1), trabeculae( 2 )

\section{Discussion}

The microscopic structure of spleen at different ages in antenatal period was discussed which gave an idea how the final structure was attained through this developmental period.

The following parameters of the developing human fetus were studied in the present study:

1. Body weight of fetus

2. Crown rump length

3. Microscopic structure of spleen at different gestational age.

All the parameters were compared with the gestational age of fetus.

1. Body weight of fetus: The findings of the present study about body weight showed gradual increase from $14^{\text {th }}$ week to $38^{\text {th }}$ weeks of gestation (table-1). When the findings of present study were compared with those of different scientists (table-10), it was found that, the body weight reported by $\operatorname{Arey}^{2}(1954)$, Gruenwald $e t a l^{3}(1960)$, Schulz et $a l^{4}(1962)$ and Potter et $\boldsymbol{a l}^{5}$ (1976) were less than the present study. However, the findings of the present study were comparable with the findings reported by Parulekar ${ }^{6}(\mathbf{1 9 9 5})$. The body weight upto $28^{\text {th }}$ week of gestation was found to be greater than reported by Hamilton $\boldsymbol{e t} \boldsymbol{a l ^ { 7 }}$ (1962) but it was comparable thereafter upto the $38^{\text {th }}$ week of gestation.

Table 2: Showing comparison of fetal body weight (gms) of present study with other workers

\begin{tabular}{|c|c|c|c|c|c|c|c|}
\hline $\begin{array}{c}\text { Gestational } \\
\text { age in } \\
\text { weeks }\end{array}$ & $\begin{array}{c}\text { Arey } \\
\mathbf{1 9 5 4}\end{array}$ & $\begin{array}{c}\text { Gruenwald } \\
\mathbf{1 9 6 0}\end{array}$ & $\begin{array}{c}\text { Hamilton } \\
\mathbf{1 9 6 2}\end{array}$ & $\begin{array}{c}\text { Schulz } \\
\mathbf{1 9 6 2}\end{array}$ & $\begin{array}{c}\text { Potter \& } \\
\text { Craig } \\
\mathbf{1 9 7 6}\end{array}$ & $\begin{array}{c}\text { Parulekar } \\
\mathbf{1 9 9 5}\end{array}$ & $\begin{array}{c}\text { Present } \\
\text { study }\end{array}$ \\
\hline 14 & - & - & - & - & 38 & 110 & 130.83 \\
\hline 16 & 105 & - & 73 & - & 73 & 200 & 200 \\
\hline 18 & - & - & - & - & 161 & 320 & 300.25 \\
\hline 20 & 310 & - & 200 & 316 & 227 & 460 & 420.50 \\
\hline 22 & - & - & - & - & 348 & 630 & 610 \\
\hline 24 & 640 & 638 & 530 & 748 & 361 & 820 & 802 \\
\hline 26 & - & 845 & - & - & 394 & 1000 & 1150 \\
\hline 28 & 1080 & 1020 & 845 & 1127.5 & - & 1300 & 1290 \\
\hline 30 & - & 1230 & - & - & 1431 & 1700 & 1725 \\
\hline 32 & 1670 & 1488 & 1940 & 1748 & 1900 & 2100 & 1924 \\
\hline 34 & - & 1858 & - & - & 2348 & 2500 & 2480 \\
\hline 36 & 2400 & 2165 & 3025 & 2448 & 2555 & 2900 & 2910 \\
\hline 38 & - & 2678 & - & - & 2879 & 3400 & 3150 \\
\hline
\end{tabular}

2. Crown rump length: The crown rump length of the fetus at different gestational age was also measured in mms. The crown rump length at 14 week gestation was $115 \mathrm{~mm}$ whereas it was $330 \mathrm{~mm}$ at 38 week.

The findings of the present study were tabulated in table- 3 for comparison with crown rump findings of the previous workers.

From the table it was seen that the values of crown rump length given by Moore $\boldsymbol{e t} \mathbf{a l}^{8}{ }^{8}$ Potter $\boldsymbol{e t} \mathbf{a l} \mathbf{l}^{5}$ (1976) and Hamilton et $^{\boldsymbol{a l}^{7}}{ }^{\mathbf{( 1 9 6 2})}$ were more or less similar to the findings of the present study. 
Table 3: Showing the comparison of crown rump length of fetus in mms at different gestational age with previous workers

\begin{tabular}{|c|c|c|c|c|}
\hline $\begin{array}{c}\text { Gestational } \\
\text { age (weeks) }\end{array}$ & Moore & $\begin{array}{c}\text { Hamilton } \\
1962\end{array}$ & $\begin{array}{c}\text { Potter and } \\
\text { Craig 1976 }\end{array}$ & $\begin{array}{c}\text { Present } \\
\text { study }\end{array}$ \\
\hline 14 & 120 & - & - & 115 \\
\hline 16 & 140 & $61-100$ & - & 122 \\
\hline 18 & 160 & - & - & 150 \\
\hline 20 & 190 & $101-200$ & - & 172 \\
\hline 22 & 210 & - & - & 185 \\
\hline 24 & 230 & $151-200$ & 209 & 202 \\
\hline 26 & 250 & - & 234 & 224 \\
\hline 28 & 270 & $201-260$ & 254 & 270.5 \\
\hline 30 & 280 & - & 271 & 276 \\
\hline 32 & 300 & $261-320$ & 284 & 295 \\
\hline 34 & - & - & 298 & 300 \\
\hline 36 & 340 & $321-390$ & 324 & 324.5 \\
\hline 38 & 360 & $391-450$ & 334 & 330 \\
\hline
\end{tabular}

3. Microscopic structure of spleen: Developmental changes in the histology of spleen were compared with the findings of different scientists.

According to Hamilton et $\boldsymbol{a} \boldsymbol{l}^{7}$ (1978), mesenchymal cells of splenic condensation multiply rapidly at $4^{\text {th }}-5^{\text {th }}$ month of gestation and differentiate into erythroblasts myeloblasts, monocytes, megakaryocytes and further erythroblasts. In present study, at the $13^{\text {th }}-14^{\text {th }}$ week of age, mesenchymal condensation was seen and after this age, differentiation was seen into blood cells.

However, Copenhaver et $^{\boldsymbol{a l}^{\mathbf{9}}}$ (1978) stated that fetal spleen participated in development of lymphocytes, erythrocytes and granular leucocytes and erythropoietic function ceased at about $8^{\text {th }}$ month.

While in the present study, we have observed the haemopoetic cells throughout, all the stages studied, i.e. from $13^{\text {th }}$ to $36^{\text {th }}$ weeks of gestation.

Van Furth et $\boldsymbol{a l}^{\mathbf{1 0}}$ (1965) observed that the white pulp of spleen showed lymphoid blast cells having larger chromatin and poor nucleus having nucleolus. Older fetuses showed increase in number of lymphocytes. Germinal centres were not observed. The red pulp showed distinct cytoplasmic pyrinophilic cells having cytoplasm with round, chromatin nucleus.

According to Potter $\boldsymbol{e t} \boldsymbol{a} \boldsymbol{l}^{\mathbf{5}}$ (1976) spleen was made up of only connective tissue and reticular cells during first two trimesters. At birth the appearance of spleen is fairly similar to the adult spleen except the less amount of connective tissue. White pulp consisted of lymphoid cells, arranged in sheath like manner around all major branches of splenic artery. Red pulp of spleen consisted of endothelium lined sinusoids, which were much prominent at birth. In our study, connective tissue framework was seemed to be formed from $13^{\text {th }}$ week onwards.

Hamilton $\boldsymbol{e t} \boldsymbol{a} \boldsymbol{l}^{7}$ (1978) stated that in early stages splenic condensation becomes arranged into anastomosing trabeculae. Trabecular columns produced reticular fibres which became connective tissue framework of spleen during histological changes splenic artery comes to open in spaces called sinusoids which are devoid of endothelial lining. Some lining cells of sinusoids became specialized to form a part of reticuloendothelial system.

Copenhaver $\boldsymbol{e t} \boldsymbol{a l} \boldsymbol{l}^{9}$ (1978) stated that white pulp showed enlargement but definite nodules did not form until late fetal stage. Germinal centres did not appear until after birth. Same findings were noted in present study.

Vellguth et $\boldsymbol{a l} \boldsymbol{l}^{\mathbf{1 1}}$ (1985) studied the development of human spleen from $14^{\text {th }}$ to $24^{\text {th }}$ week of age. He stated three stages in the development.

1. Developmental stage of the primary vascular reticulum- from 14th week of age

2. Transformation stage with formation of lobulesfrom $15^{\text {th }}$ to $18^{\text {th }}$ week of age

3. Developmental stage of lymphoid colonizationfrom $18^{\text {th }}$ to $24^{\text {th }}$ week of age

In preliminary stage, connective tissue fibres and vascular system was started developing. Reticular cells were seen and the number of blood vessels increased. At $14^{\text {th }}$ week, arteries have a continuous endothelial wall connected by desmosomes. Venus sinuses are very rare at this stage. In $13^{\text {th }}$ and $14^{\text {th }}$ week of age, mesenchymal condensation forming the connective tissue and the developing blood vessels were noted which was consistant with Vellguth et $\boldsymbol{a l} .^{11}$

In transformation stage, from $15^{\text {th }}$ week, splenic lobules began to form in the primary vascular reticulum. In the present study, the blood vessels 
seemed to be developing in the trabeculae but distinct lobules were not seen at this stage.

In developmental stage, from $18^{\text {th }}$ week, there was lymphoid colonization around the arterioles. White pulp was recognizable during the $19^{\text {th }}$ and $20^{\text {th }}$ week of age. Same was noted in our study. Between $20^{\text {th }}$ to $24^{\text {th }}$, remarkable growth in the white pulp was seen while red pulp seemed to cease its extension. In $24^{\text {th }}$ week, white pulp occupied about $50 \%$ of organ volume, which was in contradiction to the proportion in the postnatal spleen, where red pulp made up more than $80 \%$ of volume. These findings indicate alternative proliferation phases of red and white pulp.

\section{Conclusion}

Thirty fetuses of different age groups were used in the present study. The body weight and crown-rump length were recorded. The mean value was calculated for different stages of gestation. To study the histology of spleen, sections of spleen at different gestational ages were taken and stained with H\&E. The slides were observed under light microscope.

In the present study, body weight showed gradual increase from $13^{\text {th }}$ to $38^{\text {th }}$ week of gestation. The mean body weight of fetuses was $130.83 \mathrm{gms}$ at the age of $14^{\text {th }}$ week, $802 \mathrm{gms}$ at the age of $24^{\text {nd }}$ week and $3150 \mathrm{gms}$ at the age of $38^{\text {th }}$ week.

\section{Histological development of the spleen}

In the present study, following findings were noted

\section{At $\mathbf{1 3}^{\text {th }}-14^{\text {th }}$ week:}

1. Thin capsule, reticular cells, lymphoblasts and few blood vessels were seen.

2. Irregular network of mesenchymal cells were present at this stage.

\section{At $20^{\text {th }}$ week:}

1. Red and white pulp were seen prominantly.

2. Lymphocytes were compactly arranged surrounding the arterioles.

At $22^{\text {nd }}$ to $38^{\text {th }}$ week:

1. Structure was exactly similar with that of adult spleen.

Hence our study showed the developmental and histological changes in the human fetal spleen at various gestational age of fetus. From this, we concluded that haemopoetic activity of spleen was seen from $14^{\text {th }}$ week onwards and adult picture of spleen was seen from 22th week onwards.

Our study may be regarded as a preliminary study including some detailed results. We hope that the histological findings acquired in our study will be beneficial for the evaluations about the fetal spleen.
2. Arey LB. Determination of age of embryo. Developmental anatomy. London, Soundars Company, $6^{\text {th }}$ ed. 1954. p.103-6

3. Grueunwald P, Hoang NM. Evaluation of body and organ weights in perinatal pathology. Am J Clin Pathol 1960 Sept;34(3):247-53.

4. Schulz DM, Giordano DA, Schulz DH. Weight of organs of fetuses and infants. Arch Pathol Lab Med 1962;74:244-50.

5. Potter, Craig. Weights standards for organs for early human fetuses. Pathology of fetus and infants. Chicago Year Book Medical $3^{\text {rd }}$ ed. 1976. p.15-24.

6. Parulekar SV. Criteria for determination of fertilization age during fetal period. Practical anatomy, 1995, $1^{\text {st }}$ ed, p.361.

7. Hamilton, Mossman. Histogenesis of spleen. Human Embryology, Mamillan Press Ltd. London, $4^{\text {th }}$ ed. 1978. p. 363.

8. Moore K, Persaud. The Developing Human:Clinically Oriented Embryology $8^{\text {th }}$ ed. Philadelphia; W. B. Saunders Company; 2008. p. 198-202, Moore, Persaud. The Developing human. Crown rump length, body weight chart. $6^{\text {th }}$ ed. p. 109.

9. Copenhaver WM, Kelly, Wood. Development and histogenesis of spleen. Bailey's textbook of histology, $17^{\text {th }}$ ed.1978. p. 420.

10. Van Furth R, Schuit HRE, Hijmans W. The immunological development of human fetus. Journal of Experimental Medicine 1965;122:1173

11. Vellguth S, von Gaudecker B, Müller-Hermelink HK. The development of the human spleen. Ultrastructural studies in fetuses from the 14th to 24th week of gestation. Cell Tissue Res. 1985;242(3):579-92.

\section{References}

1. Cesta MF. Normal structure, function, and histology of the spleen. Toxicol Pathol. 2006 Jan;34(5):455-65. 